\title{
Impact of Thermal Treatment and Ozone on Quality Parameters and Shelf-Life of
} Mango Nectar

\author{
Sameh A. Sabk ${ }^{2}$, Roauf M. Saadany ${ }^{1}$, Osama M. Morsy ${ }^{3}$, and \\ Mohamed K. Morsy ${ }^{*}$ \\ ${ }^{1}$ Food Technology Department, Faculty of Agriculture, Benha University, Qaluobia Governorate, 13736, Egypt. \\ ${ }^{2}$ Juice Quality Department, Oryx Land Company, $10^{\text {th }}$ of Ramadan, El-Sharkia Governorate, Egypt \\ ${ }^{3}$ Department of Basic and Applied Sciences, Faculty of Engineering, Arab Academy of Science, Technology, \\ and Maritime Transport, Cairo, Egypt. \\ *Corresponding author: Mohamed Khairy Morsy, \\ Tel.: +2 012 23831825; fax: +2 0132467786.
}

Corresponding author: mohamed.abdelhafez@fagr.bu.edu.eg

\begin{abstract}
The aim of this research is to improve the quality and shelf-life of mango nectar using ozone and/or in combination with thermal hurdle treatments. The effects of four treatments i.e. pasteurization at $92 \pm 1^{\circ} \mathrm{C}$ for 16 sec; (T1), sterilization at $100 \pm 1{ }^{\circ} \mathrm{C}$ for $15 \mathrm{sec}$; (T2), ozone with $40 \mathrm{ppm}+70{ }^{\circ} \mathrm{C}$ for $30 \mathrm{~min}$; (T3), and ozone with 20 $\mathrm{ppm}+76{ }^{\circ} \mathrm{C} 30 \mathrm{~min}$; (T4) on the physical, chemical, sensory, and microbiological quality of mango nectar were evaluated. The chemical analysis i.e. moisture, available carbohydrates, and mineral contents have non-significant differences $(P>0.05)$ between all treatments. The T1 had significantly lower $(P<0.05)$ in ash and crude fiber contents than the other treatments $(P<0.05)$. The color values demonstrated that $\mathrm{L}^{*}$ value was the highest in $\mathrm{T} 2$, while $\mathrm{a}^{*}$ and $\mathrm{b}^{*}$ was the highest in T3 and T4 up to 6 months of storage. Ozone treatment, particularly T4, maintained the lowest titratable acidity and highest $\mathrm{pH}$ value in nectar throughout the storage period, followed by T3. The T3 recorded highest T.S.S., vit. C, and total carotenoids in nectar, whereas T4, retained the highest total phenolic values. The sensory acceptability of nectar revealed that T4, had the best characteristics i.e. odor, taste, and appearance scores, as well as the best microbial quality when compared to the others treatments. Finally, tested ozone hurdles, particularly T4, produced the best nectar quality. Results demonstrated that novel technology (Hurdle technology) is the best way for keeping quality and safety of nectars.
\end{abstract}

Keywords: Mango nectar; thermal treatment; ozone; quality parameters; shelf-life

\section{Introduction}

Fruit nectar (FN) is the most important product in Egypt and worldwide. The FN is a good source of carbohydrates, vitamins, minerals, and fibers as well bioactive compounds i.e. tocopherols, carotenoids, polyphenols, and phenolic (Liu, 2013, Kongkachuichai et al. 2015). FN has health benefits such as inflammation, cardiovascular diseases, cancer, and aging-related disorders (Escudero-López et al., 2016). However, the shelf life of FN is short and heat treatments affect of nutritive value as well acceptability. Mango fruit is very important raw material for making juices, especially nectars. Also, it is widely spread all over the world with a production of over 25.1 million tones, while in Egypt 1.473 tones (FAOSTAT, 2018). The quality of nectar is one of the important criteria for judging the consumer for election. Where the quality elements such as nutritional value, sensory attribute, and microbial quality. Therefore, different preservation methods are used to keep the juice quality, such as heat treatments and modern methods.Williams et al. (2005) reported lower efficacy of single ozone treatment for the inactivation of E. coli O157:H7 and Salmonella in unpasteurized apple cider and orange juice compared to a combination treatment of ozone and antimicrobial agents such as dimethyl dicarbonate and hydrogen peroxide, which achieved a 5-log reduction. When apple juice $\left(18^{\circ} \mathrm{Brix}\right)$ was treated with $0.90 \mathrm{~g} / \mathrm{h}$ ozone gas at room temperature, about 0.5 and $4.5 \mathrm{log}$ $\mathrm{CFU} / \mathrm{ml}$ reductions of $E$. coli $\mathrm{O} 157: \mathrm{H} 7$ were observed after $30 \mathrm{~s}$ and $60 \mathrm{~s}$, respectively (Choi et al., 2012). Unpasteurized apple cider and orange juice containing E. coli $\mathrm{O} 157: \mathrm{H7}$ and S. Typhimurium were treated with gaseous ozone at 4,20 , and $50^{\circ} \mathrm{C}$ (Williams $\boldsymbol{e t}$ al., 2004). Heat treatments processing is the most common method for extending the shelf life of nectar by inactivating microorganisms and enzymes, which relies on a mathematical calculation to ensure the safety of the products Thermal process design is normally adopted to maximize microbial inactivation with minimal collateral degradation to product quality (Bopel, 1995). Pasteurization and sterilization of mango nectar, puree generally led to a decrease in the levels of vitamin A, phenolics total carotenoids, and ascorbic acid were reported to be stable depending on the severity of the process (Vasquez-Caicedo et al., 2007 and Djioua et al., 2009).

Modern methods such as ozone and hardly technology has successfully proven to be one possible candidate for fruits and vegetable preservation, providing antimicrobial, and antioxidant (i.e., increased vitamin $\mathrm{C}$ and phenolic content) activities. However, discrepancies in results are often found in the literature due to the great number of variables that 
may influence ozone efficacy for preservation of fruits and vegetables. These include the $\mathrm{O} 3$ generation and application method, $\mathrm{O} 3$ concentration, duration time, method of $\mathrm{O} 3$ exposure, storage conditions, commodity, and microbes. The bactericidal effect of gaseous ozone on apple juice has been reported by several studies. Choi et al. (2012) investigated the effect of the solid content of apple juice on gaseous ozone against E. coli O157:H7, S. Typhimurium and L. monocytogenes. Patil et al. (2010) studied the antimicrobial efficacy of gaseous ozone against E. coli in apple juice of various $\mathrm{pH}$ levels. However, there have been very few research studies investigating the bactericidal effect when apple juice is treated with both heat and ozone gas simultaneously and their effect on quality changes of apple juice. Therefore, in this study, we investigated the combination or synergistic effect of ozone and heat treatments on apple juice to inactivate $E$. coli $\mathrm{O} 157: \mathrm{H} 7, S$. Typhimurium and L. monocytogenes. Also, changes in color and residual ozone of apple juice after treatment were investigated

The aim of this work is investigate the effect of thermal treatment and ozone on quality parameter microbe of load and sensor acceptability on mango nectar.

\section{Materials and methods}

\subsection{Materials}

Mango pulp (Mangifera indica L.) variety Zebdyia, $12.1^{\circ} \mathrm{Bx}$ season 2018 were purchased from Kaha Company for preserved Foods, Kaha, Qalyabia governorate, Egypt. Citric acid, ascorbic acid, and pectin were purchased from El-Naser Company (Cairo, Egypt). Sugar was supplied from a local market, Cairo, Egypt. Glass bottles volume $200 \mathrm{~mL}$ and $1000 \mathrm{~mL}$ were purchased from El-Motahda Company, Cairo, Egypt.

\subsection{Preparation of mango nectar:}

Mango nectar ( $25 \%$ of mango pulp) was prepared as recommended methods described by Egyptian Standard: ES- 7650/2013. The mango pulp was mixed with sugar solution, citric acid, pectin to get total soluble solids $15 \pm 1 \%$ and $\mathrm{pH} 3.5 \pm 0.1$. The mango nectar was divided to four Treatments $\mathrm{T} 1$ Pasteurization at $92 \pm 1^{\circ} \mathrm{C}, \mathrm{T} 2$ Sterilization at $100 \pm 1^{\circ} \mathrm{C}$, T3 $40 \mathrm{ppm}$ of Ozone at $70^{\circ} \mathrm{C}$, and $\mathrm{T} 4$ Hardly technology $20 \mathrm{ppm}$ of Ozone at $76^{\circ} \mathrm{C}$. Afterward, the nectar was filled in glass bottles 200 and $1000 \mathrm{~mL}$, then closed tightly and stored under ambient temperature $\left(25 \pm 1{ }^{\circ} \mathrm{C}\right)$.

\subsection{Heat treatments:}

\subsubsection{Pasteurization:}

Pasteurization of nectar was conducted at $92 \pm 1^{\circ} \mathrm{C}$ for $16 \mathrm{sec}$ in pasteurizer unit (Alfa Laval, Model 2015, Turkey), then stored at room temperature $\left(25 \pm 1^{\circ} \mathrm{C}\right)$ for 6 months (Mostafa et al., 1997).

\subsubsection{Sterilization:}

Sterilization by combined heat and Peak
Expiratory Flow (PEF) treatment can be used in low acid products like mango to avoid color change and to inactivate bacteria spores and enzymes. A standard thermal treatment of these purees is at $100 \pm 1{ }^{\circ} \mathrm{C}{ }^{\circ} \mathrm{C}$; for $15 \mathrm{sec}$ due to the puree color was changes of mango Product and process can be improved by using a lower temperature followed by PEF treatment in less than a second.

\subsubsection{Ozone treatment:}

Ozone gas was generated in a closed system using water ozone user (Model SY- 004, Taiwan) by corona discharge method in a $200 \mathrm{~mL}$ beaker. The fixed ozone output concentration at $600 \mathrm{mg} / \mathrm{h}$ was measured using an ozone sensor (Model 200 Series, Aeroqual, New Zealand). Ozone gas was directly pumped into the juice for up to $30 \mathrm{~min}$ through the food-grade silicone tube into the beaker and stirred using magnetic stirrer $(100 \mathrm{rpm})$ to ensure the ozone molecules were completely mixed with the nectar. The gas flow rate was fixed at $0.2 \mathrm{~L} / \mathrm{min}$ and temperature treatment was fixed at $20^{\circ} \mathrm{C}$. Untreated mango nectar and treated fruit juice were stored at $4 \pm 1^{\circ} \mathrm{C}$ in sterile dark glass bottles to protect from light. All experiments were carried out in triplicate and analyses were immediately performed after processing (within an hour).

Experiments were carried out in a $250 \mathrm{ml}$ bubble column with a built-in diffuser. Ozone was generated using an ozone generator (Model OL80, Ozone services, Canada). Oxygen flow rate was controlled using a gas flow regulator. The experimental design for this work was based upon a parallel inactivation study for E. coli $\mathrm{O} 157: \mathrm{H} 7$, using the same control conditions. A 5-log reduction was achieved in under $5 \mathrm{~min}$ at an optimum flow rate of $0.1251 \mathrm{~min} 1$ and a maximum ozone concentration obtainable $(4.8 \% \mathrm{w} / \mathrm{w})$ at this flow rate (Patil et al., 2009). Ozone concentration in the gas supply was varied (1-4.8\% w/w of oxygen) and recorded using an ozone gas analyses (Model OLA-DLS, Ozone services). Ozone treatments were performed at $20 \pm 0.5^{\circ} \mathrm{C}$.

\subsubsection{Porximate chemical composition of mango pulp and nectar:}

The moisture, ash, crude fiber, titratable acidity, total sugars, reducing sugars, non-reducing sugars, ascorbic acid and minerals, content were determined according to the method described by the AOAC (2016).

\subsubsection{Physical properties:}

The $\mathrm{pH}$ value was measured by using a $\mathrm{pH}$ meter model consort $\mathrm{pH}$ meter $\mathrm{p} 107$, according to AOAC (2016).T.S.S. was mesarued using Abbe referctometer model $1 \mathrm{~T}$ at $20^{\circ} \mathrm{C}$ according to AOAC (2016).

\subsubsection{Determination of carotenoids:}

Carotenoids were determined according to (Nagata and Yomashita., 1992).

Carotenoids content was calculated by equation follows as equations: Carotenoids $(\mathrm{mg} / 100 \mathrm{~mL}$ of 
extract $)=$

$$
\begin{array}{r}
(0.216 \times \text { OD } 663-122 \times \text { OD } 645-0.304 \times \text { OD } 505+ \\
0.452 \times \text { OD } 453) .
\end{array}
$$

\subsubsection{Color measurements:}

Color of nectars was measured using Hunter Lab instrument at the Horticultural research institute, Agricultural research center, Egypt. Model D 65 color and color difference meter (C1E LAB 10/D 65). Results were expressed as load per gram, where $\mathrm{L}^{*}$ value (indicates of lightness), $\mathrm{a}^{*}$ value indicates of (redness to gereenness) and the $b^{*}$ value indicates (Yellowness to blueness) as described by Hunter, (1959).

\subsection{Determination of total phenolic content:}

Total phenolic content of all treatments were analyzed according to the folin-Ciocalteu method (Veligolu et al., 1998).

\subsection{Microbiological examination:}

Total viable bacterial count and total coliforms, yeasts and molds, thermo flic were enumerated according to the methods established by American Public Health Association (APHA, 1992).

Moulds and yeasts: were counted according to the methods describes by (APHA, 1992).

2.7. Sensory evaluation:

Sensory evaluation were carried out by properly well trained panel of the 15 member internal panel evaluated the different nectars blends for color, odor appearance, taste, and overall acceptability. Mineral water was used by the panelists to rinse the mouth between samples. Pastor et al. (1996). The Sensory evaluation for fruit nectar was done before and during storage periods.

2.8. Statistical analysis:

The statistical analysis was carried out using two-way ANOVA using SPSS, ver. 25 (IBM Corp. Released 2013). Data were treated as a complete randomization design according to Steel et al. (1997). The significance level was set at $<0.05$.

3. Results and discussion

3.1. Proximate chemical composition and mineral contents:

Mango pulp is an important raw material for producing the nectar. Data in Table (1), showed that the moisture, protein, fat, ash, fiber, and available carbohydrates contents of mango pulp were 86.30, $0.72,0.23,0.60,1.81$ and $10.34 \%$, respectively. Also, the chemical composition of mango nectar treatments were ranged from: 84.28-84.90\% moisture, 0.20$0.22 \%$ crude protein, $0.05-0.06 \%$ fat, $0.18-0.20 \%$ ash, $0.34-0.39$ crude fiber and $14.27-14.90 \%$ available carbohydrate.

\begin{tabular}{|c|c|c|c|c|c|c|c|c|c|c|}
\hline \multirow{2}{*}{\multicolumn{2}{|c|}{ Treatments }} & \multicolumn{6}{|c|}{ Components (\%) } & \multicolumn{3}{|c|}{$\begin{array}{l}\text { Mineral contents }(\mathrm{mg} / 100 \\
\mathrm{g})\end{array}$} \\
\hline & & $\begin{array}{c}\text { Moistu } \\
\text { re }\end{array}$ & $\begin{array}{c}\text { Crude } \\
\text { protei } \\
\text { n } \\
\end{array}$ & Fat & Ash & $\begin{array}{c}\text { Crude } \\
\text { fiber }\end{array}$ & $\begin{array}{c}\text { Available } \\
\text { carbohyd } \\
\text { rate* }\end{array}$ & $\mathbf{C a}$ & $\mathbf{K}$ & $\mathbf{F e}$ \\
\hline & Iango pulp & 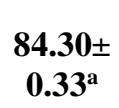 & $\begin{array}{c}0.72 \pm 0 \\
.01^{\mathrm{a}}\end{array}$ & $\begin{array}{c}0.23 \pm 0 \\
.01^{\mathrm{a}}\end{array}$ & $\begin{array}{c}0.60 \pm 0 \\
01^{\mathrm{a}}\end{array}$ & $\begin{array}{c}1.81 \pm 0 \\
.011^{\mathrm{a}}\end{array}$ & $\begin{array}{c}12.34 \pm 0.3 \\
6^{b}\end{array}$ & $\begin{array}{l}14.38 \pm \\
0.49^{\mathrm{a}}\end{array}$ & $\begin{array}{c}157.00 \pm \\
1.73^{a}\end{array}$ & $\begin{array}{c}0.15 \pm 0 \\
.00^{\mathrm{a}}\end{array}$ \\
\hline & $\begin{array}{l}\text { Control } \\
\text { sample }\end{array}$ & $\begin{array}{c}\text { 84.72 } \pm \\
\mathbf{0 . 2 3}^{b}\end{array}$ & $\begin{array}{l}0.21 \pm 0 \\
.01^{b}\end{array}$ & $\begin{array}{c}0.06 \pm 0 \\
.00^{b}\end{array}$ & $\begin{array}{l}0.19 \pm 0 . \\
01^{\mathrm{c}}\end{array}$ & $\begin{array}{l}0.35 \pm 0 \\
.01\end{array}$ & $\begin{array}{c}14.47 \pm 0.2 \\
2^{\mathrm{a}}\end{array}$ & $\begin{array}{l}3.86 \pm 0 . \\
04^{b}\end{array}$ & $\begin{array}{c}35.11 \pm 1 \\
.07^{b}\end{array}$ & $\begin{array}{l}0.04 \pm 0 \\
.00^{b}\end{array}$ \\
\hline $\begin{array}{l}\mathbf{T} \\
\mathbf{1}\end{array}$ & $\begin{array}{c}\text { Pasteuriz } \\
\text { ation }\end{array}$ & $\begin{array}{c}\text { 84.73士 } \\
\mathbf{0 . 2 3}^{\mathrm{b}}\end{array}$ & $\begin{array}{c}0.22 \pm 0 \\
.01^{b}\end{array}$ & $\begin{array}{c}0.06 \pm 0 \\
.00^{b}\end{array}$ & $\begin{array}{c}0.18 \pm 0 \\
01^{\mathrm{c}}\end{array}$ & $\begin{array}{c}0.34 \pm 0 \\
.01^{\mathrm{c}}\end{array}$ & $\begin{array}{c}14.47 \pm 0.2 \\
2^{\mathrm{a}}\end{array}$ & $\begin{array}{c}3.96 \pm 0 \\
04^{\mathrm{b}}\end{array}$ & $\begin{array}{c}35.14 \pm 1 \\
.07^{b}\end{array}$ & $\begin{array}{c}0.04 \pm 0 \\
.00^{b}\end{array}$ \\
\hline $\begin{array}{l}\mathbf{T} \\
2\end{array}$ & $\begin{array}{l}\text { Sterilizat } \\
\quad \text { ion }\end{array}$ & $\begin{array}{c}\text { 84.84士 } \\
0.40^{b}\end{array}$ & $\begin{array}{c}0.20 \pm 0 \\
.01^{b}\end{array}$ & $\begin{array}{c}0.05 \pm 0 \\
.00^{b}\end{array}$ & $\begin{array}{c}0.20 \pm 0 \\
00^{b}\end{array}$ & $\begin{array}{c}0.39 \pm 0 \\
.00^{b}\end{array}$ & $\begin{array}{c}14.32 \pm 0.4 \\
1^{\mathrm{a}}\end{array}$ & $\begin{array}{l}3.96 \pm 0 \\
03^{b}\end{array}$ & $\begin{array}{c}36.67 \pm 0 \\
.77^{\mathrm{b}}\end{array}$ & $\begin{array}{c}0.04 \pm 0 \\
.00^{b}\end{array}$ \\
\hline $\begin{array}{l}\mathbf{T} \\
\mathbf{3}\end{array}$ & $\begin{array}{c}40 \text { ozone } \\
\text { at } 70^{\circ} \mathrm{C}\end{array}$ & $\begin{array}{c}\text { 84.90士 } \\
\mathbf{0 . 1 8}^{\mathrm{b}}\end{array}$ & $\begin{array}{c}0.21 \pm 0 \\
.00^{b}\end{array}$ & $\begin{array}{c}0.05 \pm 0 \\
.00^{b}\end{array}$ & $\begin{array}{c}0.19 \pm 0 . \\
00^{b c}\end{array}$ & $\begin{array}{c}\mathbf{0 . 3 8} \pm 0 \\
.00^{b}\end{array}$ & $\begin{array}{c}14.27 \pm 0.1 \\
8^{\mathrm{a}}\end{array}$ & $\begin{array}{l}3.85 \pm 0 \\
08^{b}\end{array}$ & $\begin{array}{c}36.50 \pm 0 \\
.87^{b}\end{array}$ & $\begin{array}{c}0.04 \pm 0 \\
.00^{b}\end{array}$ \\
\hline $\begin{array}{l}T \\
4\end{array}$ & $\begin{array}{l}20 \text { ozone } \\
\text { at } 76^{\circ} \mathrm{C}\end{array}$ & $\begin{array}{c}\text { 84.28 } \pm \\
0.15^{b}\end{array}$ & $\begin{array}{l}0.20 \pm 0 \\
.00^{b}\end{array}$ & $\begin{array}{c}0.05 \pm 0 \\
.00^{\mathrm{b}}\end{array}$ & $\begin{array}{c}0.19 \pm 0 . \\
00^{\text {be }}\end{array}$ & $\begin{array}{l}0.38 \pm 0 \\
.00^{b}\end{array}$ & $\begin{array}{l}14.90 \pm 0.1 \\
6^{a}\end{array}$ & $\begin{array}{l}3.95 \pm 0 . \\
09^{b}\end{array}$ & $\begin{array}{c}35.67 \pm 0 \\
.77^{b}\end{array}$ & $\begin{array}{l}0.04 \pm 0 \\
.00^{b}\end{array}$ \\
\hline
\end{tabular}

Table 1. Chemical composition and mineral contents of mango pulp and nectar (mean $\pm \mathrm{SE}$ ) (on wet basis).

* Available carbohydrate calculated by difference.

a, b \& c: There is no significant difference $(P>0.05)$ between any two means, within the same column have the same superscript letter. 
The results revealed that there is non significant difference $(\mathrm{P}>0.05)$ in moisture, protein, fat and available carbohydrate contents for all nectar treatments, while there is a significant difference in ash and crude fiber contents. These results are in agreement with those reported by Tharanathan et al. (2006) who found that the chemical composition of mature mango fruit were: moisture content 78.90$82.80 \%$, ash content $0.34-52 \%$, total lipid content $0.30-0.53 \%$, total protein $0.36-0.40$, total dietary fiber $0.85-1.06 \%$ and total carbohydrate $16.20-17.18 \%$ (on wet basis). Kilima (2014) found that the total soluble solids (TSS) for mango, was $14.03^{\circ}$ Brix. Whiles Abdelrahman (2021) found that the chemical composition of mango juice for moisture, T.S.S., ash, crude protein and fat contents was 81.87, 15.83, 0.69, 0.83 and $0.58 \%$, respectively. While, mango nectar was $80.55,17.23,0.28,0.18$ and $0.11 \%$, respectively. USDA (2018) reported that the total carbohydrate and sugar contents of Tommy Atkins, Haden, Kent and Keitt cultivars were 14.98 and $13.66 \%$, respectively (sucrose, $6.97 \mathrm{~g}$; glucose, $2.01 \mathrm{~g}$; and fructose, $4.68 \mathrm{~g}$ ) and $1.6 \mathrm{~g}$ of dietary fiber/100 $\mathrm{g}$ of fruit.

Results in the some table shown that the content mango pulp of minerals such as $\mathrm{Ca}, \mathrm{K}$ and $\mathrm{Fe}$ was $14.38,0.157$ and $0.04 \mathrm{mg} / 100 \mathrm{~mL}$, respectively. The obtained data in shown that a significant difference in $\mathrm{Ca}, \mathrm{K}$ and $\mathrm{Fe}$ content between mango pulp and different treatments. Results indicated that there is non significant difference in $\mathrm{Ca}, \mathrm{K}$ and $\mathrm{Fe}$ contents for different nectar treatments. These obtained results are in agreement with USDA (2018) reported that the essential mineral contents of edible portion of mango fruit were: Ca 7-16, Fe 0.09-41, P 10-18, and K 120-211, mg/100 g.

\section{2. Effect of heat treatments and ozone on mango nectar properties during storage:}

\subsubsection{Color parameters $\left(L^{*}, a^{*}\right.$ and $\left.b^{*}\right)$ :}

Data in Table(2). Showed that, The control samplewas rejected after 2 months.

Data in Table (2) shown that the treatments that take place on mango nectar affect on $L^{*}$ value. The highest of $L^{*}$ value was in zero time for (T1) $(46.50 \pm 0.29)$ and lowest value was in $\mathrm{T} 3$

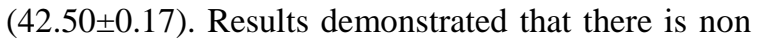
significant difference in $L^{*}$ value between T1, T2 and $\mathrm{T} 4$. Also there is non significant difference in $L^{*}$ value between T2, T3 and T4. Furthermore there is non significant difference in $L^{*}$ value between T1 and T2 and betweenT3andT 4 during storage period .These results are in agreement with those reported by Cadena et al. (2013) who found $L^{*}$ value was 50.17 in mango nectar at zero time. Data in Table (2) shown that the treatments that take place on mango nectar affect on $a^{*}$ value. The highest of $a^{*}$ value was in zero time for T3 $(2.73 \pm 0.01)$ and lowest value was in T2 $(2.19 \pm 0.02)$. Results demonstrated that there is a significant difference in $a^{*}$ value between all treatments. The obtained data in Table (2) shown that there is a significant difference between all treatments in $a^{*}$ value during storage period. The obtained results showed that T3 had the highest value of $a^{*}$ at zero time and in all period storage, while $\mathrm{T} 2$ had the lowest value at zero time and during all storage periods. These results are in agreement with those reported by Cadena et al. (2013) who found $a^{*}$ value was 3.95 in mango nectar at zero time. They found there is a significant increase with increasing period.Data in Table (2) shown that the treatments that take place on mango nectar affect on $b^{*}$ value as the highest of $b^{*}$ was in zero time for T3 $(18.68 \pm 0.20)$ and lowest content was in T1 (15.14 \pm 0.05$)$. Results demonstrated that there is a significant difference in $b^{*}$ content between all treatments. There is a significant difference between all treatments in $b^{*}$ content during storage period. The obtained results showed that T3 had the highest value of $b^{*}$ content at zero time and during period storage, while $\mathrm{T} 1 \mathrm{had}$ the lowest value at zero time and during storage periods. There is a significant decrease in T1 $(12.90 \pm 0.52)$ compared other treatments. These results are in agreement with Cadena et al. (2013) who found that $b^{*}$ value was 16.03 in mango nectar at zero time. They found there is a significant increase with increasing period. Also, they found the color parameters ( $\left.\mathrm{L}^{*}, \mathrm{a}^{*}, \mathrm{~b}^{*}\right)$ underwent significant $(\mathrm{p}<0.05)$ alterations throughout the shelf life. Kumar et al. (2013) found that the control juice sample had redness $\left(a^{*}\right)$, yellowness $\left(b^{*}\right)$ and luminosity $\left(\mathrm{L}^{*}\right)$ values of $0.14 \pm 0.005$, $20.61 \pm 0.005$ and $19.62 \pm 0.010$, respectively. The redness $\left(\mathrm{a}^{*}\right)$, yellowness $\left(\mathrm{b}^{*}\right)$ and luminosity $\left(\mathrm{L}^{*}\right)$ value of mango nectar increased significantly $(\mathrm{p}<0.05)$ after thermal processing and also throughout the storage. The increase in the Luminosity ( $\left.\mathrm{L}^{*}\right)$ values evidently indicated the degradation of carotene pigment in mango nectar. 
Table 2. Effect of different heat processing and ozone on $L^{*}, a^{*}$ and $b^{*}$ values of mango nectar (mean $\left.\pm \mathrm{SE}\right)$.

\begin{tabular}{|c|c|c|c|c|c|}
\hline \multirow{3}{*}{ Treatments } & \multicolumn{4}{|c|}{ Storage period (month) } & \multirow{3}{*}{$\begin{array}{c}\text { Mean of } \\
\text { storage } \\
\text { periods }\end{array}$} \\
\hline & $\mathbf{0}$ & 2 & 4 & 6 & \\
\hline & \multicolumn{4}{|c|}{$L^{*}$} & \\
\hline Control & $46.51 \pm 0.29$ & $\mathbf{R} *$ & - & - & \\
\hline T1 & $46.50 \pm 0.29^{\mathrm{aC}}$ & $48.76 \pm 0.15^{\mathrm{aBC}}$ & $50.61 \pm 0.24^{\mathrm{aB}}$ & $53.36 \pm 0.08^{\mathrm{aA}}$ & $49.81 \pm 0.76^{a}$ \\
\hline $\mathbf{T} 2$ & $45.10 \pm 0.05^{\mathrm{abC}}$ & $50.63 \pm 0.22^{\mathrm{aB}}$ & $52.54 \pm 0.12^{\mathrm{aB}}$ & $55.10 \pm 0.05^{\mathrm{aA}}$ & $50.84 \pm 1.11^{\mathrm{a}}$ \\
\hline $\mathbf{T 3}$ & $42.50 \pm 0.17^{\mathrm{bB}}$ & $43.50 \pm 0.20^{\mathrm{bB}}$ & $44.63 \pm 0.25^{\mathrm{bB}}$ & $47.16 \pm 0.10^{\mathrm{bA}}$ & $44.45 \pm 0.53^{b}$ \\
\hline T4 & $44.02 \pm 0.02^{\mathrm{abC}}$ & $44.45 \pm 0.15^{\mathrm{bBC}}$ & $46.99 \pm 0.06^{b B}$ & $49.29 \pm 10.26^{\mathrm{bA}}$ & $46.19 \pm 3.54^{b}$ \\
\hline \multirow[t]{2}{*}{$\begin{array}{l}\text { Mean of } \\
\text { treatments }\end{array}$} & $44.53 \pm 0.95^{C}$ & $46.84 \pm 1.40^{\mathrm{BC}}$ & $48.69 \pm 1.64^{\mathrm{AB}}$ & $51.23 \pm 3.24^{\mathrm{A}}$ & \\
\hline & \multicolumn{4}{|c|}{$a^{*}$} & \\
\hline Control & $2.55 \pm 0.03$ & $\mathbf{R}^{*}$ & - & - & \\
\hline T1 & $2.56 \pm 0.03^{\mathrm{cC}}$ & $2.72 \pm 0.01^{b B}$ & $2.77 \pm 0.01^{\mathrm{cA}}$ & $2.80 \pm 0.00^{\mathrm{bA}}$ & $2.71 \pm 0.05^{c}$ \\
\hline $\mathbf{T} 2$ & $2.19 \pm 0.02^{\mathrm{dD}}$ & $2.44 \pm 0.12^{\mathrm{cC}}$ & $2.53 \pm 0.02^{\mathrm{dB}}$ & $2.60 \pm 0.01^{\mathrm{cA}}$ & $2.44 \pm 0.05^{d}$ \\
\hline T3 & $2.73 \pm 0.01^{\mathrm{aD}}$ & $2.82 \pm 0.00^{\mathrm{aC}}$ & $2.89 \pm 0.00^{\mathrm{aB}}$ & $3.00 \pm 0.01^{\mathrm{aA}}$ & $2.86 \pm 0.03^{a}$ \\
\hline T4 & $2.66 \pm 0.01^{\mathrm{bC}}$ & $2.78 \pm 0.01^{\mathrm{aB}}$ & $2.80 \pm 0.01^{\mathrm{bAB}}$ & $2.83 \pm 0.02^{\mathrm{bA}}$ & $2.77 \pm 0.02^{b}$ \\
\hline \multirow[t]{2}{*}{$\begin{array}{c}\text { Mean of } \\
\text { treatments }\end{array}$} & $2.54 \pm 0.27^{\mathrm{D}}$ & $2.69 \pm 0.25^{C}$ & $2.75 \pm 0.24^{B}$ & $2.81 \pm 0.25^{A}$ & \\
\hline & \multicolumn{4}{|c|}{$b^{*}$} & \\
\hline Control & $15.13 \pm 0.05$ & $\mathbf{R}^{*}$ & - & - & \\
\hline $\mathbf{T 1}$ & $15.14 \pm 0.05^{\mathrm{dA}}$ & $13.80 \pm 0.03^{\mathrm{dB}}$ & $12.03 \pm 0.01^{\mathrm{dD}}$ & $10.62 \pm 0.02^{\mathrm{dC}}$ & $12.90 \pm 0.52^{d}$ \\
\hline $\mathbf{T} 2$ & $16.51 \pm 0.02^{\mathrm{cA}}$ & $15.93 \pm 0.04^{\mathrm{cB}}$ & $15.25 \pm 0.13^{\mathrm{cC}}$ & $13.10 \pm 0.03^{\mathrm{cD}}$ & $15.20 \pm 0.39^{c}$ \\
\hline T3 & $18.68 \pm 0.20^{\mathrm{aA}}$ & $18.24 \pm 0.00^{\mathrm{aB}}$ & $17.83 \pm 0.10^{\mathrm{aC}}$ & $17.59 \pm 0.03^{\mathrm{aD}}$ & $18.09 \pm 0.13^{a}$ \\
\hline $\mathbf{T 4}$ & $17.94 \pm 0.05^{\mathrm{bA}}$ & $17.82 \pm 0.10^{\mathrm{bB}}$ & $17.10 \pm 0.08^{b C}$ & $16.22 \pm 0.15^{\mathrm{bD}}$ & $17.27 \pm 0.21^{b}$ \\
\hline $\begin{array}{c}\text { Mean of } \\
\text { treatments }\end{array}$ & $17.07 \pm 1.56^{A}$ & $16.45 \pm 1.63^{B}$ & $15.55 \pm 1.75^{\mathrm{C}}$ & $14.23 \pm 1.89^{D}$ & \\
\hline
\end{tabular}

$L^{*}$ value $=$ indicates degree of lightness $* L=$ luminosity; $a *$ value $=$ indicates degree of redness to greenness and $b *$ value $=$ indicates yellowness to blueness

a, b \& c: There is no significant difference $(P>0.05)$ between any two means, within the same column have the same superscript letter.

A, B \& C: There is no significant difference $(P>0.05)$ between any two means for the same attribute, within the same $\mathbf{R} *$ Rejected row have the same superscript letter.

\subsubsection{Titratable acidity content and $\mathrm{pH}$ value:}

Data in Fig. (1). The control was rejected after 2 months.

Data in Fig. (1) shown that the impact of heat and ozone treatments on acidity mango nectar. The titratable acidity content as the highest content in zero time for $\mathrm{T} 2(0.42 \pm 0.00 \%)$ and lowest content was in T4 $(0.35 \pm 0.00 \%)$. Results revealed that there is a significant difference in titratable acidity content between all treatments. The obtained data in Fig. (1) shown that there is a significant difference $(P<0.05)$ between different treatments in titratable acidity content during storage period. The obtained results showed that $\mathrm{T} 2$ had the highest value of titratable acidity content at zero time and in all storage periods, while T4 had the lowest value at zero time and during all storage periods. Furthermore there is significant increase in titratable acidity content for mean of treatments with increasing storage period. Abdelrahman (2021) reported that acidity $0.37 \%$ mango nectar, was brix $17.23^{\circ}$ and served as an ideal recipe for nectar.

Data in Fig. (1). The control was rejected after 2 months.

Data in Fig. (2) showed that there is a significant difference $(P<0.05)$ in $\mathrm{pH}$ value between different treatments. Also, there is a significant difference $(P<0.05)$ between all treatments in $\mathrm{pH}$ value during storage period. The obtained results showed that $\mathrm{T} 2$ had the lowest value of $\mathrm{pH}$ value in zero time and during period storage, while $\mathrm{T} 4 \mathrm{had}$ the highest value at zero time and during all storage periods.These results are in agreement with Cadena et al. (2013) who found the titratable acidity $0.15 \%$ and $\mathrm{pH}$ values 4.13 of the mango nectars at zero time, there were no significant differences $(p>0.05)$ between the different samples, the values did not change during the shelf life. Abdelrahman (2021) reported that $25 \%$ mango pulp, $17.23^{\circ}$ brix and $\mathrm{pH}$ value was 3.80 . 


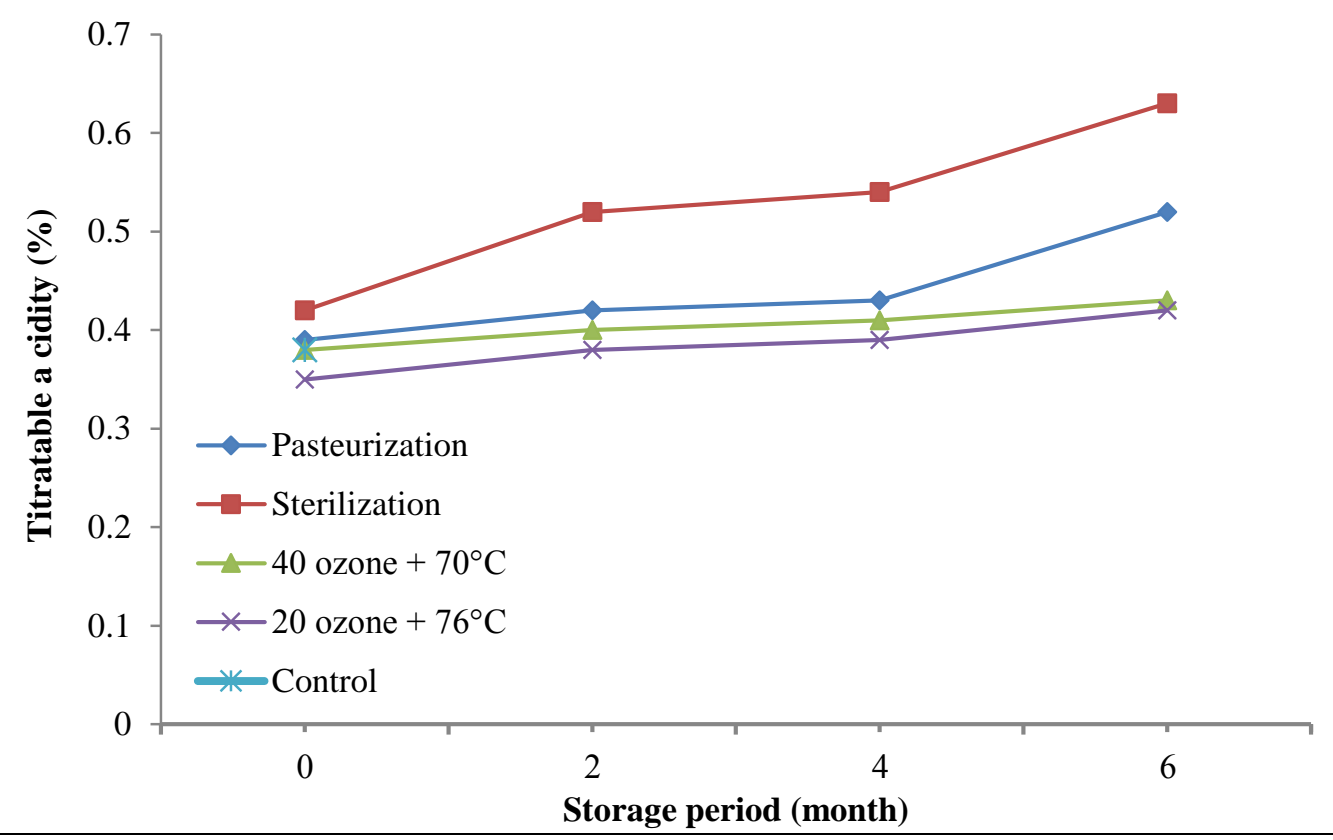

Fig. (1). Effect of heat and ozone treatments on titratable acidity in mango nectar during storage period at $25^{\circ} \mathrm{C}$.

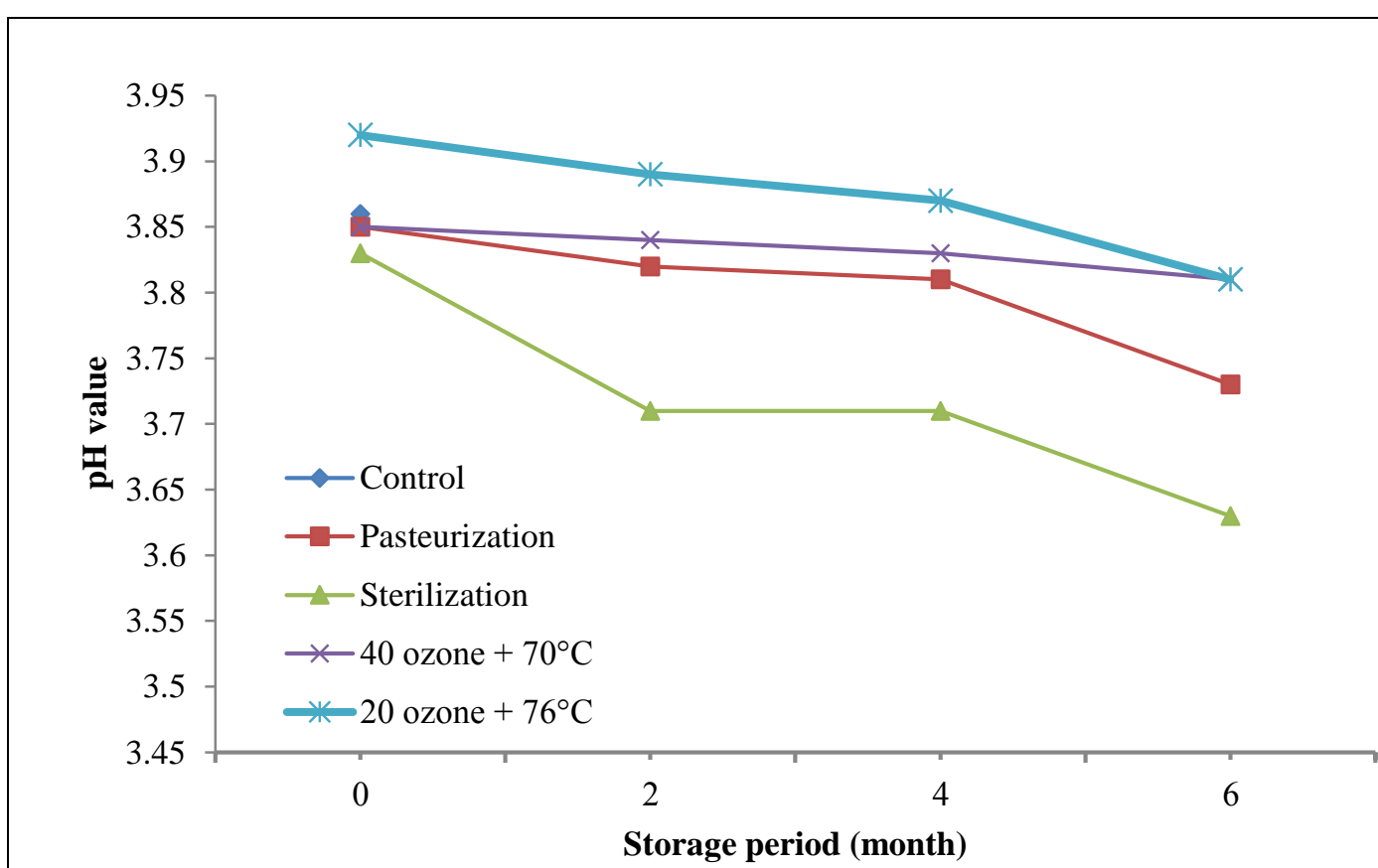

Fig. (2). Effect of heat and ozone treatments on $\mathrm{pH}$ value in mango nectar during storage period at 25 ${ }^{\circ} \mathrm{C}$.

Data in Fig. (3) shown that the impact of heat and ozone treatments on mango nectar. The T.S.S. content as the highest content in zero time for $\mathrm{T} 4$ $(15.30 \pm 0.06 \%)$ and lowest content was in $\mathrm{T} 1$ $(14.85 \pm 0.03 \%)$. Results revealed that there is a significant difference in T.S.S. content between T4 compared with other treatments. Also, there is non significant difference between T3 and T4 in T.S.S. content during storage period, while, there is a significant difference between T3 compared with other treatments.Regardless of the different treatments, the obtained data shown that there is a 
significant decrease in T.S.S. content for mean of treatments with increasing storage period. Rregardless of the storage period, there is non significant difference in T.S.S. content between T3 and T4; while there is a significant decrease in T1 $(14.66 \pm 0.04 \%)$ compared other treatments. These results are in agreement with those reported by Cadena et al. (2013) who found the T.S.S. was $14.00 \%$ of the mango nectars at zero time. Comparing the given results with Egyptian standardizations (not less than $15.1 \%$ ) and international limits (not less than $13.5 \%$ ), while Babarinde et al. (2019) reported that the T.S.S. of mango nectar values obtained from samples prior to storage ranged from 11.50 to $14.30^{\circ}$ brix.

Data in Fig. (4) shown that the Vit. C content was the highest content in zero time for $\mathrm{T} 3$ $(17.40 \pm 0.10 \mathrm{mg} / 100 \mathrm{~mL})$ and lowest content was in T2 $(13.23 \pm 0.01 \mathrm{mg} / 100 \mathrm{~mL})$. Results revealed that there is a significant difference in vit. $\mathrm{C}$ content between all treatments. Fig. (4). Also, that there is a significant difference between $\mathrm{T} 3$ and other treatment in TSS content during storage period. The obtained results showed that $\mathrm{T} 3$ had the highest value of Vit. C content at zero time and during period storage, while T2 had the lowest value at zero time and during all storage periods. Regardless of the different treatments, the obtained data in Fig. (4) shown that there is a significant decrease in Vit. C with increasing storage period. Rregardless of the storage period, there is a significant difference in Vit. C content between $\mathrm{T} 3$ and other treatments while there is a significant decrease in T2 $(11.31 \pm 0.38 \mathrm{mg} / 100$ $\mathrm{mL}$ ) compared other treatments. These results are in agreement with reported by Abdelrahman (2021) who found that the ascorbic acid content of mango nectar was $13.54 \mathrm{mg} / 100 \mathrm{~g}$ sample. Kumar et al. (2013) found that ascorbic acid content of fresh mango nectar was found to be $9.2 \pm 0.005 \mathrm{mg} / 100 \mathrm{~mL}$. While thermally treated $\left(780 \mathrm{sec}\right.$ at $\left.96^{\circ} \mathrm{C}\right)$ samples had $5.17 \pm 0.005 \mathrm{mg} / 100 \mathrm{~mL}$. The color, and ascorbic acid content of the mango nectar were significantly $(p<0.05)$ reduced during storage period at temperature $\left(27-30^{\circ} \mathrm{C}\right)$ but still the quality of the nectar was good up to 180 days.

Data in Fig. (5) shown that the impact of heat and ozone treatments on mango nectar. The total carotenoids content as the highest content in zero time for T3(1.89 $\pm 0.00 \mathrm{mg} / 100 \mathrm{~mL})$ and low content was in T2 $(1.74 \pm 0.02 \mathrm{mg} / 100 \mathrm{~mL})$. Results revealed that there is a significant difference in total carotenoids content between all treatments. The obtained results showed that T3 had the highest value of total carotenoids content at zero time and in all period storage, while T2 had the lowest value at zero time and during storage periods. Kumar et al. (2013) showed that the carotene degradation is one of the important factors to cause color change in thermally processed mango nectar. The color and carotene content of the mango nectar were significantly $(p<0.05)$ reduced during 180 days of ambient $\left(27-30^{\circ} \mathrm{C}\right)$ temperature storage, but still the quality of the nectar was good up to 180 days.

Data in Fig. (6) shown that the impact of heat and ozone treatments on mango nectar. The total phenolic content as the lowest content in zero time for T2 (44.75 $\pm 0.14 \mathrm{mg} / 100 \mathrm{~mL})$. There is non-significant difference in total phenolic content between all treatments. Also ,there is non-significant difference between $\mathrm{T} 3$ and $\mathrm{T} 4$ and between $\mathrm{T} 1$ and $\mathrm{T} 2$ in total phenolic content during storage period. The obtained results showed that T3 had the lowest value of total phenolic content at zero time and in all storage period, while T4 had the highest from storage period. The obtained results indicated that the total phenolic content less than results record by Ramirez et al. (2013). They reported that the peel of Pica cultivar from Chile presented the highest content of total phenolic compounds $(66.02 \mathrm{mg} / 100 \mathrm{~g} \mathrm{FW})$ analyzed by HPLC-PDA. 


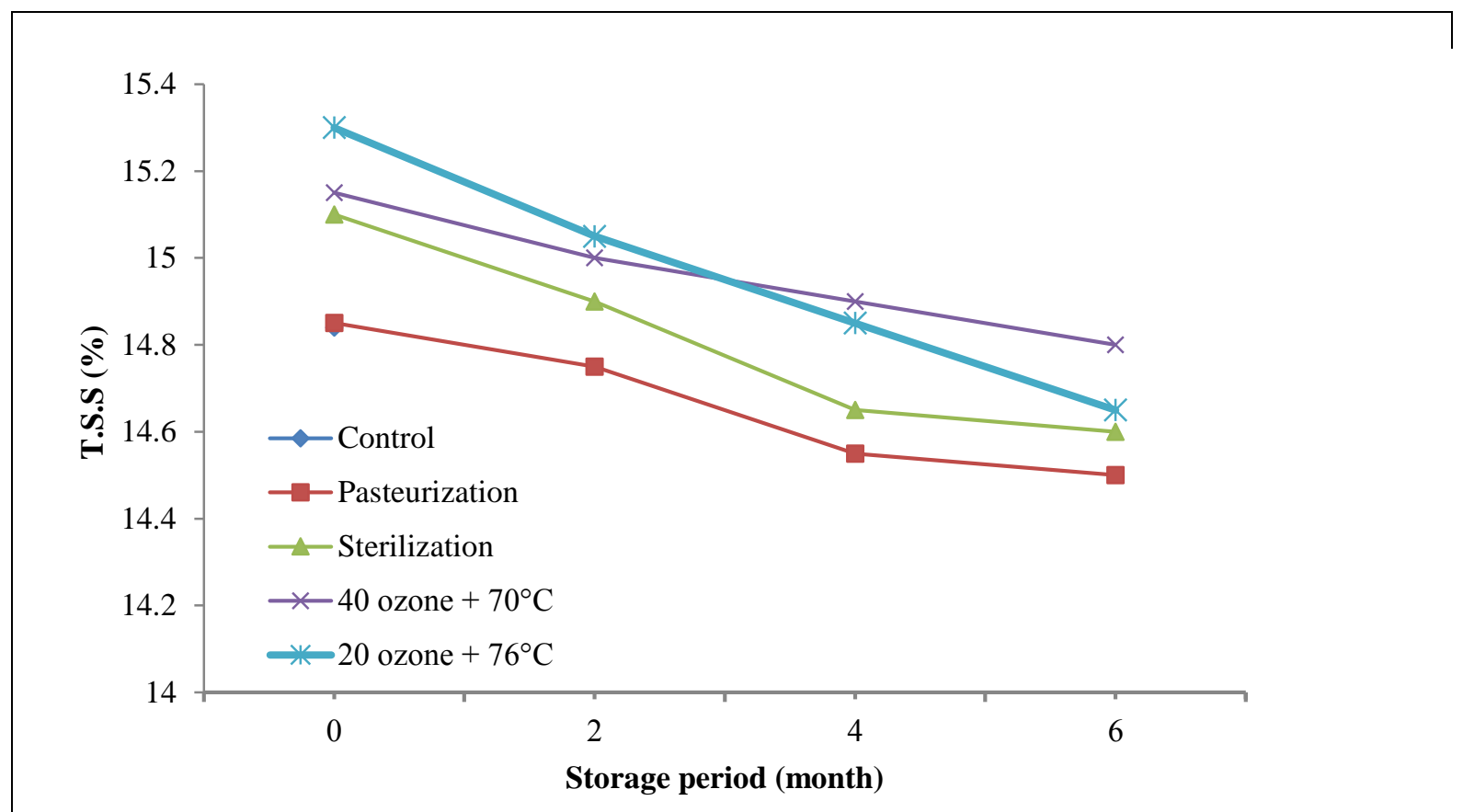

Fig. (3). Effect of heat treatments and ozone on T.S.S (\%) in mango nectar during storage period at 25 ${ }^{\circ} \mathrm{C}$.

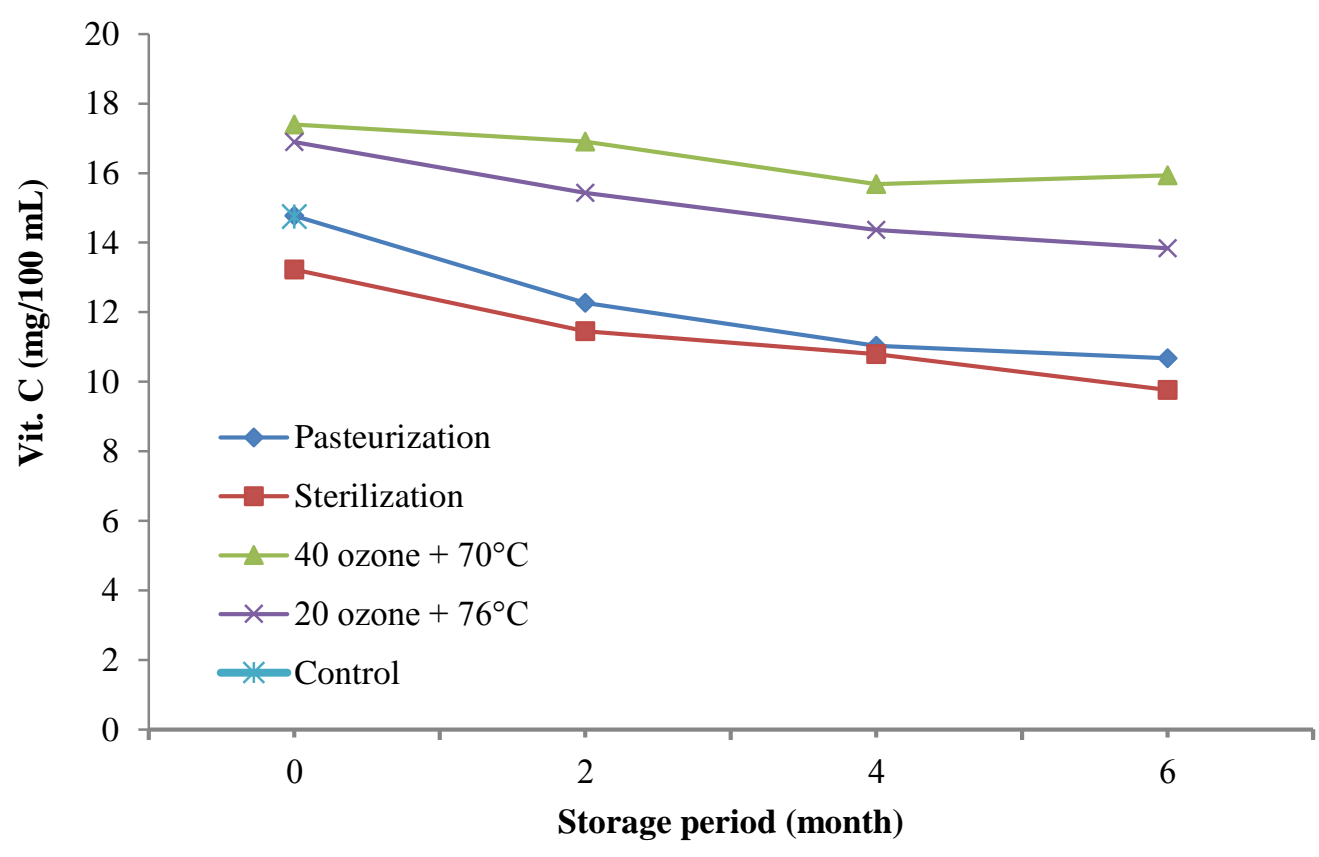

Fig. (4). Effect of heat and ozone treatments on Vit $\mathrm{C}(\mathrm{mg} / 100 \mathrm{~mL})$ in mango nectar during storage period at $25^{\circ} \mathrm{C}$. 

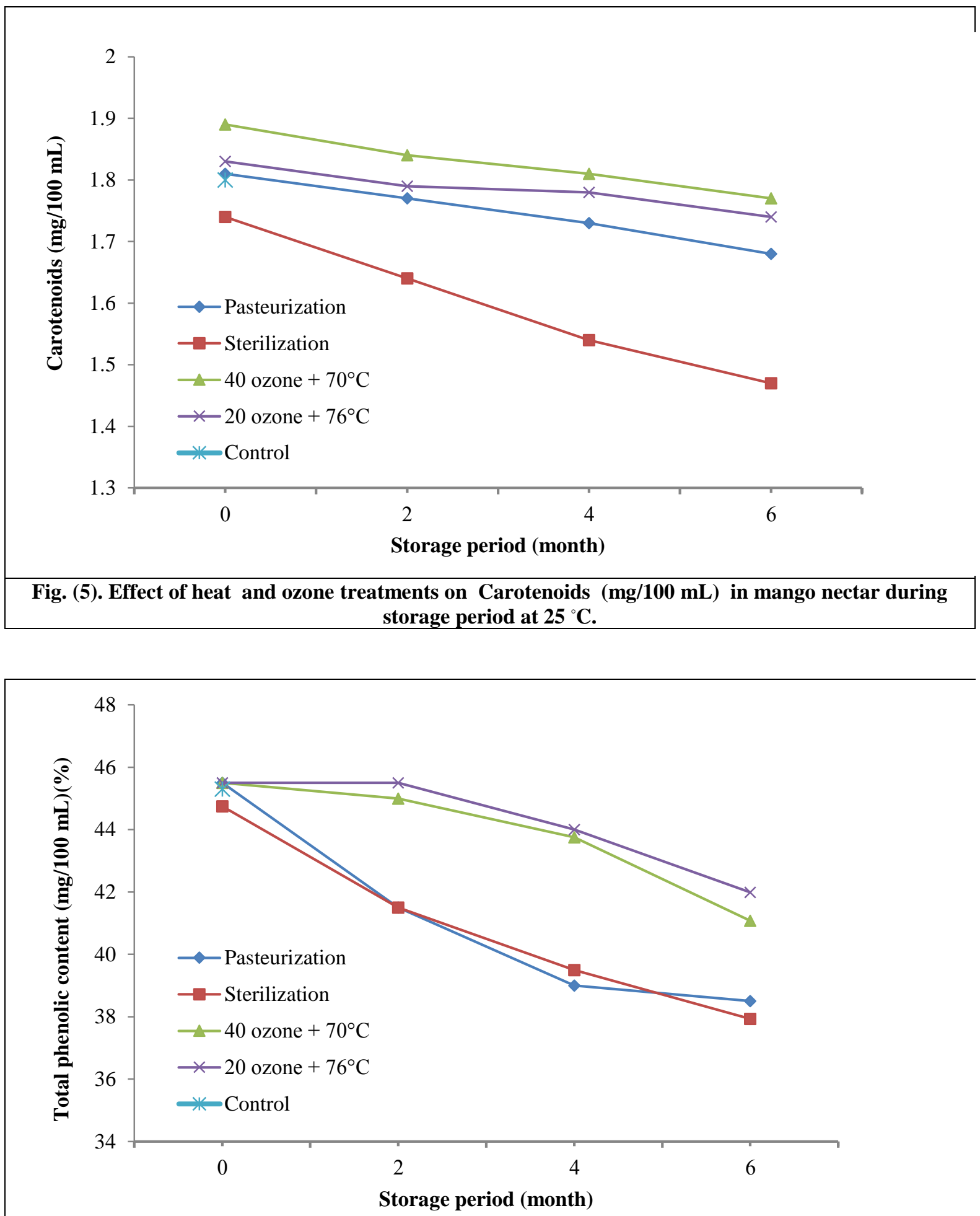

Fig. (6). Effect of heat and ozone treatments on Total phenolic content $(\mathrm{mg} / 100 \mathrm{~mL})$ in mango nectar during storage period at $25^{\circ} \mathrm{C}$.

\subsubsection{Total sugars:}

Data in Fig. (7) shown that the impact of heat and ozone treatments on mango nectar. The highest of total sugars content was in zero time for T4 ozone $(11.57 \%)$ and lowest content was in $\mathrm{T} 1$ $(11.43 \%)$. Results revealed that there is non significant difference in total sugars content between all treatments at zero time and 6 months of storage period. Also, there is non significant difference between $\mathrm{T} 3$ and $\mathrm{T} 4$ and between $\mathrm{T} 1$ and $\mathrm{T} 4$ in total sugars content during storage period while, there is a significant difference between T3 and T4 compared with $\mathrm{T} 1$ and T2. For there more there is a significant decrease in total sugars content for mean of treatments with increasing storage period. These results are in agreement with those obtained by Abu El-Maaty 
(2012) and Saad (2017). They found that the total sugars content in mango juice $10.87 \%$.Abdelrahman (2021) found that the total sugars content in mango juice and nectar were within the range between $11.22 \%$ for mango juice to $14.11 \%$ for mango nectar.

Data in Fig. (8) shown that the highest of reducing sugars content was in zero time for $\mathrm{T} 2$ $(3.36 \%)$ and lowest content was in T4 (3.19\%). Results revealed that there is non significant difference in reducing sugars content between $\mathrm{T} 2$ and T3 at zero time, also, there is non significant difference between T1, T3 and T4. Also, there is non significant difference between all treatments in reducing sugars content during storage period. The obtained results showed that $\mathrm{T} 2$ had the highest value of reducing sugars content at zero time and during period storage, while $\mathrm{T} 4$ had the lowest value at zero time and during all storage periods. Regardless of the different treatments, the obtained data in Fig. (8) shown that there is a significant decrease in reducing sugars content for mean of treatments with increasing storage period. Also, regardless of the storage period, there is non significant difference in reducing sugars content between all treatments. These results are in agreement with those reported by Abdelrahman (2021). Who found that the reducing sugars content in mango juice and nectar were within the range between $1.98 \%$ for mango juice to $2.80 \%$, for mango nectar.
Data in Fig. (9) shown that the highest of non-reducing sugars content was $(7.96 \%)$ in zero time for T4 and lowest content was in T2 $(7.75 \%)$. Results revealed that there is non significant difference in non-reducing sugars content between $\mathrm{T} 1$, $\mathrm{T} 3$ and T4 at zero time, also, there is non-significant difference between $\mathrm{T} 1$ and other treatments. Also, there is non-significant difference between all treatments in reducing sugars content at 6 months of storage period. The highest value of non-reducing sugars content at zero time, during of storage period, while $\mathrm{T} 2$ had the lowest value at zero time and 2 months of storage periods But, T1 had the lowest value at 4 and 6 months of storage periods. While there is non-significant decrease in non-reducing sugars content for mean of treatments with increasing storage period. Also, regardless of the storage period, there is non significant difference in non-reducing sugars content between $\mathrm{T} 3$ and other treatments.

These results are in agreement with those obtained by Abu El-Maaty (2012) who found that the non-reducing sugars content in mango juice was 7.67\% and Saad (2017) found that the non-reducing sugars content in mango juice was $9.06 \%$. Abdelrahman (2021) reported that the Non-reducing sugars content in mango juice and nectar were within the range between $8.78 \%$ for mango juice to $10.75 \%$ for mango nectar

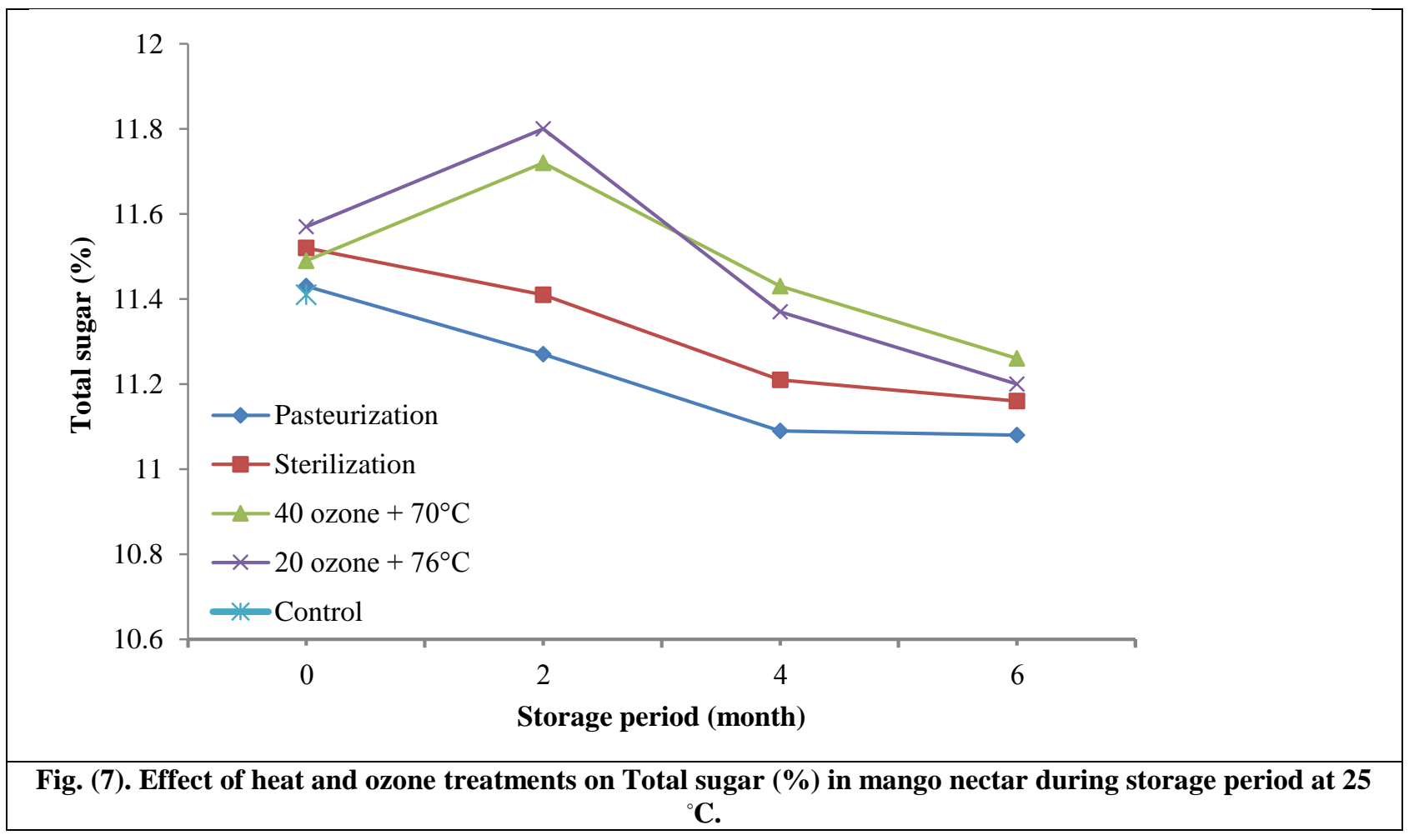



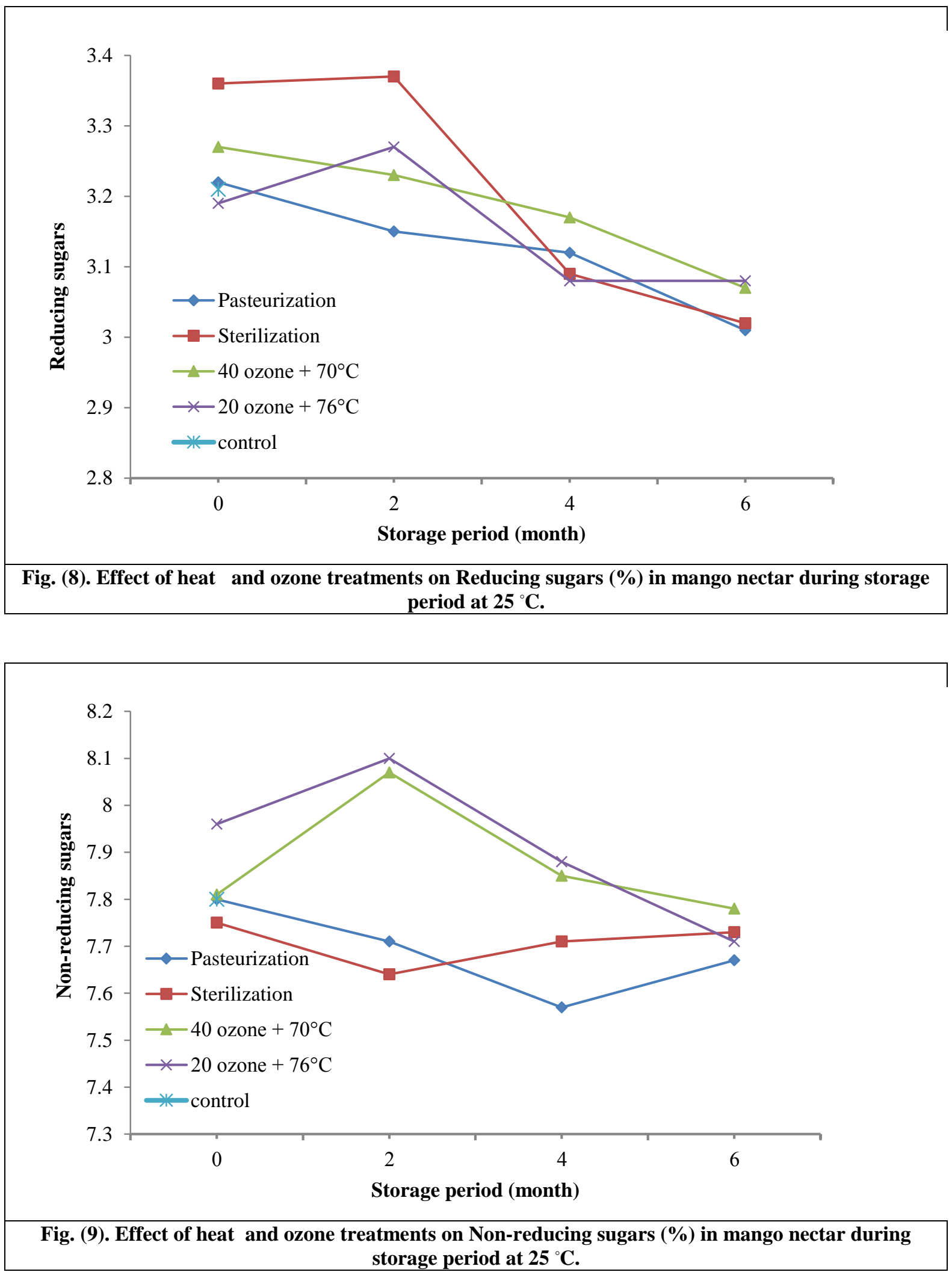

\subsubsection{Effect of storage period on sensory properties of mango nectar:}

Sensory evaluation of food product is an important criterion by which consumer acceptability can be assessed. Data in Fig. (10) shows the changes in organoleptic properties i.e. odor, color, appearance, taste and overall acceptability during storage period of mango nectar.

\subsubsection{Color score:}

The color is one of the important parameters for standardizing processing conditions. Color 
degradation of mango nectar by thermal processing was investigated using Hunter color lab instrument. The carotene degradation is one of the important factors to cause color change in thermally processed mango nectar (Kumar et al., 2013). Data in Fig.(10) showed found that there is a significant difference in color score between different treatments. Also, there is non significant difference between $\mathrm{T} 1$ and $\mathrm{T} 4$ in color score at zero time, while there is non significant difference in color score between T2 and T3 at 2 and 4 months of storage. The obtained results showed that T3 had the highest score in color at zero time (22.88 \pm 0.27$)$, while $\mathrm{T} 4$ had the lowest score (21.75 \pm 0.38$)$. While, there is a significant decrease in color score for mean of all treatments with increasing storage period. Rregardless of the storage period, there is non significant difference in color score between $\mathrm{T} 1, \mathrm{~T} 3$ and T4; T2 and T3, while there is a significant decrease in color score for $\mathrm{T} 2$ compared other treatments.

\subsubsection{Odor score:}

Data in Fig. (10) shows that there is a significant difference in odor score between T3 compared with other treatments. Alsogthere is non significant difference between $\mathrm{T} 1, \mathrm{~T} 2$ and $\mathrm{T} 4$ in odor score at zero time and after 2 months of storage period. Also there is non significant difference in odor score between $\mathrm{T} 1$, T2 and T3 at 4 months of storage. While, T3 had the highest score in odor at zero time $(22.85 \pm 0.25)$, while $\mathrm{T} 4$ had the lowest score $(21.76 \pm 0.18)$.Also, there is a significant decrease in odor score for mean of all treatments with increasing storage period. Rregardless of the storage period, there is a significant difference in odor score between different treatments, while there is non significant decrease in odor score between $\mathrm{T} 2$ and $\mathrm{T} 4$.

\subsubsection{Appearance score:}

Data in Fig. (10) shows that there is a significant difference in appearance score between T4 compared with other treatments. Alsog that there is non significant difference between $\mathrm{T} 1, \mathrm{~T} 2$ and $\mathrm{T} 4$ in appearance score at 4 months of storage period. The obtained results showed that $\mathrm{T} 4$ had the highest score in appearance at zero time $(22.00 \pm 0.28)$, while T2 had the lowest score $(18.75 \pm 0.26)$. While, there is a significant difference in appearance score for mean of all treatments with increasing storage period. Also, regardless of the storage period, there is a significant difference in appearance score between different treatments, while there is non significant decrease in appearance score between T3 and T4.

\subsubsection{Taste score:}

Data in Fig. (10) shows that there is a significant difference in taste score between T3 compared with other treatments. Also, there is non significant difference between $\mathrm{T} 1, \mathrm{~T} 2$ and $\mathrm{T} 4$ in taste score at zero time of storage period. The obtained results showed that $\mathrm{T} 3 \mathrm{had}$ the highest score in taste at zero time $(22.80 \pm 0.20)$, while $\mathrm{T} 4$ had the lowest score $(21.71 \pm 0.24)$. While, there is a significant decease in taste score for mean of all treatments with increasing storage period. Also, regardless of the storage period, there is a significant difference in taste score between different treatments, while there is non significant decrease in taste score between T3 and T4; T1 and T2.

\subsubsection{Overall acceptability score:}

Data in Fig. (10) Revealed that there is a significant difference in overall acceptability score between T3 compared with other treatments. Also, there is non significant difference between $\mathrm{T} 1$ and $\mathrm{T} 4$ in overall acceptability score at zero time from storage period. The obtained results showed that $\mathrm{T} 3 \mathrm{had}$ the highest score in overall acceptability at zero time $(90.13 \pm 0.76)$, while T2 had the lowest score $(85.13 \pm 1.32)$. Regardless of the different treatments, there is a significant difference in overall acceptability score for mean of all treatments with increasing storage period. Also, regardless of the storage period, there is a significant difference in overall acceptability score between different treatments, while there is non significant decrease in taste score between $\mathrm{T} 3$ and $\mathrm{T} 4$; T1 and T2.Kumar et al. (2013) reported that the carotene degradation is one of the important factors to cause color change in thermally processed mango nectar. The sensory scores of the mango nectar were significantly $(p<0.05)$ reduced during 180 days of ambient $\left(27-30^{\circ} \mathrm{C}\right)$ temperature storage, but still the quality of the nectar was good up to 180 days. The thermally processed RTD mango nectar had significant $(p<0.05)$ lower overall acceptability score. 


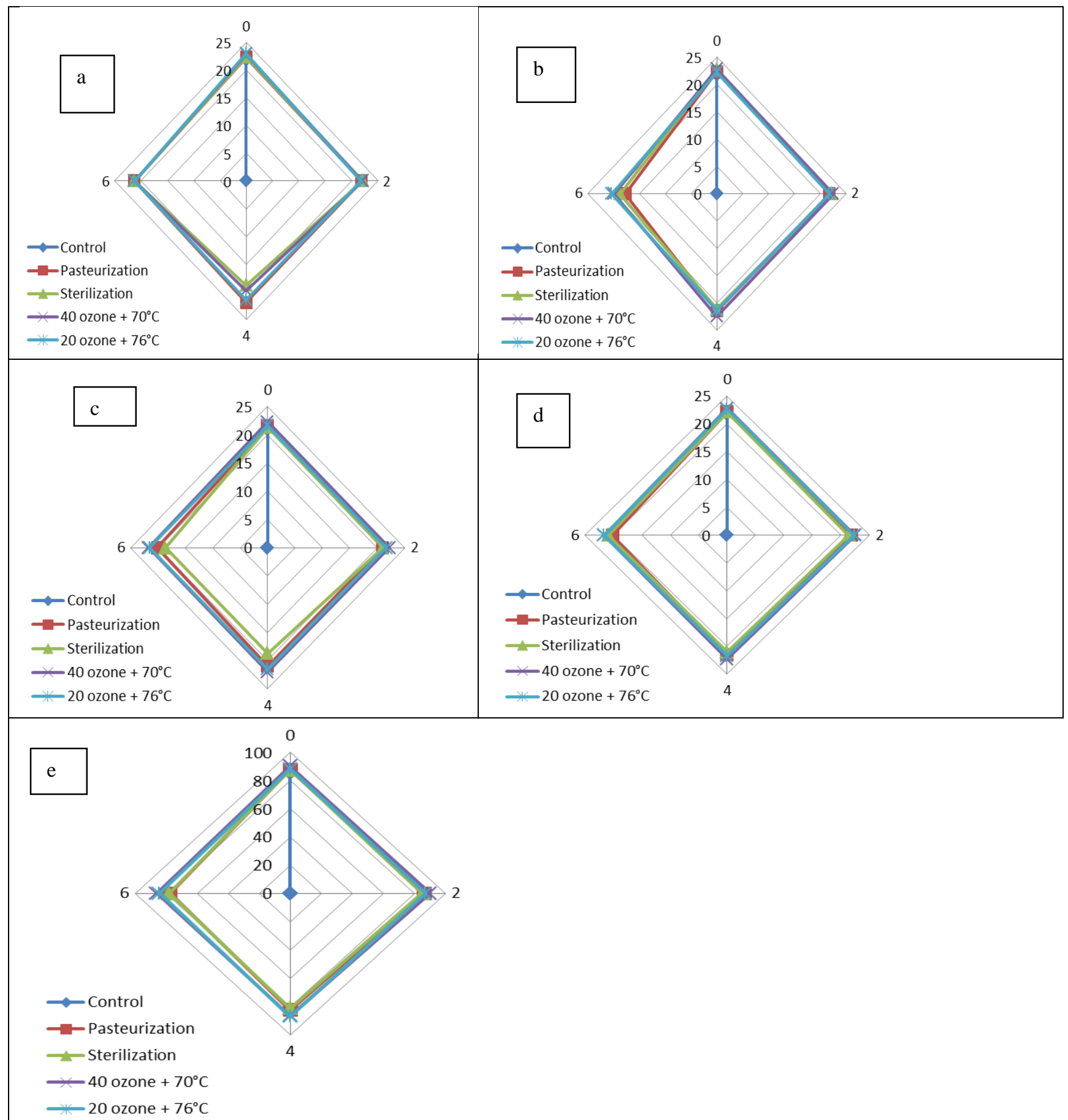

Fig. (10): Effect of different heat processing and storage periods on color (a), oder (b), appearance (c), test (d), and overall acceptability (e) mango nectar (mean $\pm \mathrm{SE})$.

\subsubsection{Microbiology quality of mango nectar:}

Data in Table (3) showed that the total bacterial count (TBC) in mango pulp was $7.2 \times 10^{6}$ $\mathrm{CFU} / \mathrm{mL}$. But, TBC was decreased in different treatments at zero time. Data shown that the total bacterial count was increased with progress storage period in all different treatments. $\mathrm{T} 1 \mathrm{had}$ given the highest content of TBC $1.8 \times 10^{5} \mathrm{CFU} / \mathrm{mL}$ at 6 months, while T4 had given the lowest number $2.1 \times 10^{4}$ $\mathrm{CFU} / \mathrm{mL}$.
By examining all samples at the beginning of storage, the mango pulp or the different treatments, it was found that they were nil of E. coli and Coliform bacteria. Also, by re-examination during storage periods, it was also found to be free from E. coli or Coliform bacteria.

Kumar et al. (2013) concluded that thermal processing at $96^{\circ} \mathrm{C}$ for a total heating time $(f h)$ of 780 $\mathrm{s}$ with pvalue of 12.73 would be a good method to produce microbiologically stable mango nectar with the good retention of quality attributes. 
Table 3. Effect of different heat processing and storage periods on total bacterial count of mango nectar.

\begin{tabular}{|c|c|c|c|c|}
\hline \multirow{2}{*}{ Treatments } & \multicolumn{4}{|c|}{ Storage period (month) } \\
\hline & $\mathbf{0}$ & 2 & 4 & 6 \\
\hline mango pulp & $6.9 \times 10^{6}$ & $6.9 \times 10^{6}$ & $7 \times 10^{6}$ & $7.1 \times 10^{6}$ \\
\hline Control & $4.7 \times 10^{6}$ & $\mathbf{R} *$ & $\mathbf{R}$ & $\mathbf{R}$ \\
\hline T1 & $1.1 \times 10^{3}$ & $2.5 \times 10^{3}$ & $1.6 \times 10^{4}$ & $1.8 \times 10^{5}$ \\
\hline $\mathbf{T} 2$ & $2.2 \times 10^{2}$ & $1.4 \times 10^{3}$ & $1.8 \times 10^{4}$ & $1.1 \times 10^{5}$ \\
\hline $\mathbf{T 3}$ & $1.9 \times 10^{2}$ & $2.3 \times 10^{3}$ & $1.5 \times 10^{4}$ & $2.4 \times 10^{4}$ \\
\hline T4 & $1.4 \times 10^{3}$ & $2.7 \times 10^{3}$ & $9.0 \times 10^{3}$ & $2.1 \times 10^{4}$ \\
\hline
\end{tabular}

\section{Conclusion}

In the current study, the impact pasteurization at $92 \pm 1^{\circ} \mathrm{C}$ for $16 \mathrm{sec}$;(T1), sterilization at $100 \pm 1{ }^{\circ} \mathrm{C}$ for 15 sec; (T2), ozone at $40 \mathrm{ppm}+70{ }^{\circ} \mathrm{C}$ for $30 \mathrm{~min}$; (T3), and ozone at $20 \mathrm{ppm}+76^{\circ} \mathrm{C} 30 \mathrm{~min}(\mathrm{~T} 4)$ on the physical, chemical, sensory, microbiological quality of mango nectar were evaluated. The moisture, available carbohydrates, and minerals content have nonsignificant differences $(P>0.05)$ between all treatments. The T1, had significantly lower $(P<0.05)$ in ash and crude fiber contents than the other treatments. The color values demonstrated that $\mathrm{L}^{*}$ value was the highest in T2, while $a^{*}$ and $b^{*}$ was the highest in T3 and T4 up to 6 months of storage. Ozone treatments, particularly $\mathrm{T} 4$, maintained the lowest titratable acidity and highest $\mathrm{pH}$ value in nectar throughout the storage period, followed by T3. The T3, recorded highest T.S.S., vit. C, and total carotenoids in nectar, whereas $\mathrm{T} 4$, retained the highest total phenolic values. The sensory acceptability of nectar revealed that $\mathrm{T} 4$, had the best characteristics i.e. odor, taste, and appearance scores, as well as the best microbial quality when compared to others treatments. Finally, tested ozone hurdles, particularly T4, produced the best nectar quality. Results demonstrated that novel technology (Hurdle technology) is the best way for keeping quality and safety of nectars.

\section{Acknowledgment}

The authors wish to express their gratitude to National Research Centre for assisting with the Microbiological examination. SAS would like to thank Benha University for all the support provided.

\section{References}

Abdelrahman, M.K.A. (2021). Chemical and technological studies on mango juice. M.Sc. Thesis, Fac. Agric., Benha Univ., Egypt.

Abu El-Maaty, A.S.M (2012). Studies on quality properties of some fruit juices. Msc. Thesis, Fac. Agric,. Benha Univ., Egypt

AOAC. (2016). Official Methods of Analysis of AOAC International $20^{\text {th }} \mathrm{ed}$. Published by AOAC International Gathersburg. Maryland, USA.

APHA (1992): Compendium of methods for the microbiological examination of foods. Inc. American public Health Association. Washington Dc.

Babarinde, G.O.; Olatunde, S.J. and AdebiyiOlabode, A. (2019). Quality attributes and phytochemical properties of fresh juice produced from selected mango varieties. Ceylon Journal of Science, 48(1): 31-36.

Cadena, R.S.; Cruz, A.G.; Netto, R.R.;Wellington Freitas Castro, W.F.; Faria, J.A.F. and Bolini, H.M.A. (2013). Sensory profile and physicochemical characteristics of mango nectar sweetened with high intensity sweeteners throughout storage time. Food Research International 54: 1670-1679.

Choi, M.R., Liu, Q., Lee, S.Y., Jin, J.H., Ryu, S.R., and Kang, D.H. (2012). Inactivation of Escherichia coli O157:H7, Salmonella Typhimurium and Listeria monocytogenes in apple juice with gaseous ozone. Food Microbiol. 32, 191-195.

Djioua, T.; Charles, F.; Lopez-Lauri, F.; Filgueiras, H.; Coudret, A.; Freire, M.; Jr.; et al. (2009). Improving the storage of minimally processed mangoes (Mangifera indica L.) by hot water treatments. Post harvest Biology and Technology, 52: 221-226.

Escudero-López, B.; Cerrillo, I.; Gil-Izquierdo, Á.; Hornero-Mèndez, D.; Herrero-Martín, G.; Bera, G.; Medina, S.; Ferreres, F.; Martín, F. and Fernández-Pachón, M.S. (2016). Effect of thermal processing on the profile of bioactive compounds and antioxidant capacity of fermented orange juice. Int. J. Food Sci. Nutr., 67:779-88.

FAOSTAT (2018). Food and Agriculture Organization Statistical, World Food and Agriculture Statistical Pocketbook,Availablefrom:http://www.fao.org/ab out/who-we are/departments/statisticsdivision/ar/.

Gould, G.W. (1995). New methods of food preservation. Glasgow: Blackie Academic and professional.

Hunter, R.S. (1959). Photoelectric color difference meter. J. Opt. Soc. Am. 48 (12) . 985. C. F. " Quality control for the food industry" vol.1, 1970. $3^{\text {rd }}$ ed., pp. 31, Kramer, A. and Twigg, B. A. eds. The AVI publishing company INC; USA 
Kilima, B.M. (2014). Physiochemical, mineral composition and antioxidant properties of Roselle (Hibiscus sabdariffa L.) extract blended with tropical fruit juices. African Journal of Food, Agriculture, Nutrition and Development

Kumar, R.; Bawa, A.S.; Kathiravan, T. and Nadanasabapathi, S. (2013). Thermal processing of mango nectar (Mangifera indica) and its effect on chemical, microbiological and sensory quality characteristics. International Journal of Advanced Research, 1(8): 261-273.

Liu, F.X.; Fu, X.F.; Chen, F.; Liao, X.J.; Hu, X.S. and Wu, J.H. (2013). Physico-chemical and antioxidant properties of four mango (Mangifera indica L.) cultivars in China. Food Chem., 138: 396-405.

Mostafa, G.A.; Abd El-Hady, E.A. and Asker, A. (1997): Preparation of papaya and mango nectar blends. Fruit processing, 3(5): 180-185.

Nagata, M. and Yamashita, I. (1992. Simple method for simultaneous determination of chlorophyll and carotenoids in tomato fruit. Nippon Shokuhin Kogyo Gakkaish, 39(10): 925-928.

Pastor, M.V.; Costell, E. and Duran, I. (1996): Effect of hydrocolloids and aspartom on sensory viscosity and sweetness of low calorie peach nectars. J. Texture Stud., 27: 61-79.

Patil, S., Valdramidis, V.P., Cullen, P.J., Frias, J., and Bourke, P. (2010). Inactivation of Escherichia coli by ozone treatment of apple juice at different pH levels. Food Microbial,. 27: 835840.

Patil, S.; Bourke, P.; Frias, J.M.; Tiwari, B.K. and Cullen, P.J. (2009). Inactivation of Escherichia coli in orange juice using ozone. Innovative Food Science and Emerging Technologies, 10(4): 551557.

Ramirez, J.E.; Zambrano, R.; Sepulveda, B. and Simirgiotis, M.J. (2013). Antioxidant properties and hyphenated HPLC-PDA-MS profiling of
Chilean Pica mango fruits (Mangifera indica L. cv. piqueno). Mol. 19: 438-458.

Saad, A.M.A. (2017). Studies on production, quality and characteristics of some juice blends. Ph.D. Thesis. Food Technology Dep., Fac. Agric., Benha Univ., Egypt.

Steel, R.; Torrie, J. and Dickey, D. (1997): Principles and procedures of Statistics: A Biometrical Approach, $3^{\text {rd }}$ ed., McGraw-Hill, New York, NY.

Tharanathan, R.N.; Yashoda, H.M. and Prabha, T.N. (2006). Mango (Mangifera indica L.), the king of fruits-an overview. Food Rev. Int., 22: 95123.

USDA (2018). USDA-United States Department of Agriculture, Agricultural Research Service. USDA National Nutrient Database for Standard Reference, Release 1 April, Nutrient Data Laboratory Home Page

Vasquez-Caicedo, A.L.; Schilling, S.; Carle, R. and Neidhart, S. (2007). Effects of thermal processing and fruit matrix on $\beta$-carotene stability and enzyme inactivation during transformation of mangoes into puree and nectar. Food Chemistry, 102: 1172-1186.

Velioglu, Y.S.; Mazza, G.; Gao, L. and Oomah, B.D. (1998). Antioxidant activity and total phenolics in selected fruits, vegetables, and grain products. Journal of Agriculture and Food Chemistry, Davis, v. 46, n. 10, p. 4113-4117,

Williams, R.C., Sumner, S.S., and Golden, D.A. (2004). Survival of Escherichia coli O157:H7 and Salmonella in apple cider and orange juice as affected by ozone and treatment temperature. J. Food Prot. 67, 2381-2386.

Williams, R.C., Sumner, S.S., and Golden, D.A. (2005). Inactivation of Escherichia coli $\mathrm{O} 157: \mathrm{H} 7$ and Salmonella in apple cider and orange juice treated with combinations of ozone, dimethyl dicarbonate, and hydrogen peroxide. J. Food Sci. 70, M197-M201. 


\section{تأثيرالمعاملات الحراريه والأوزن علي معايير الجودة والصلاحيةعلي نكتار المانجو}

سامح سابق , رؤف السعدني, اسامه البدري, محمد خبري

إستهدفت هذه الدراسة تحسين جودة وسلامة نكتار المانجو بإستخدام بعض طرق الحفظ التقليدية والحديثة (المعاملات الحرارية، الأوزون، تكنولوجيا

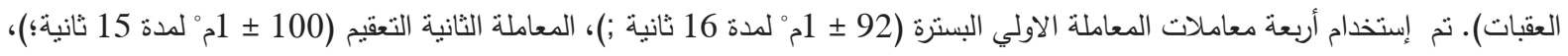

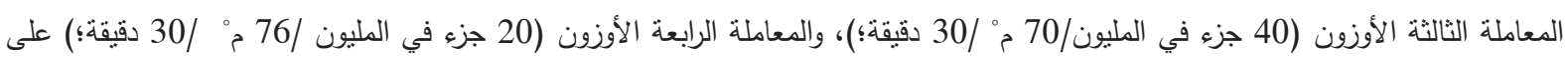

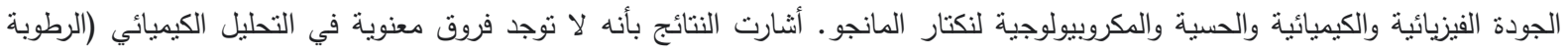

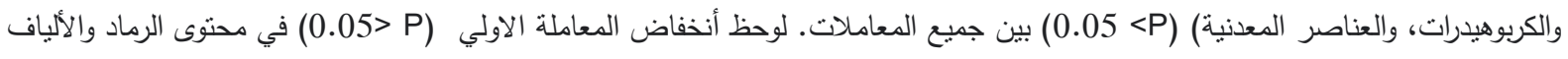

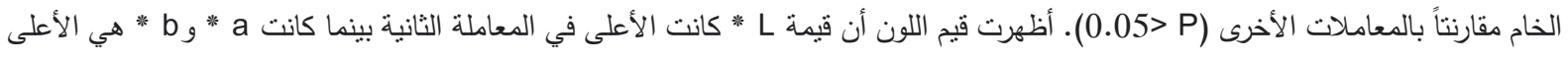

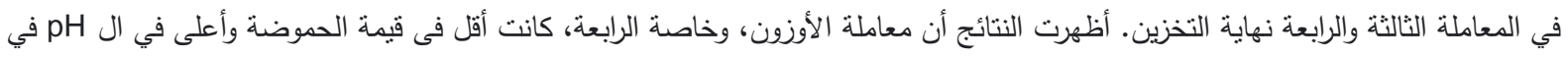

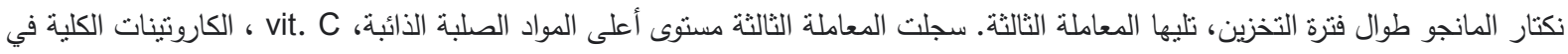

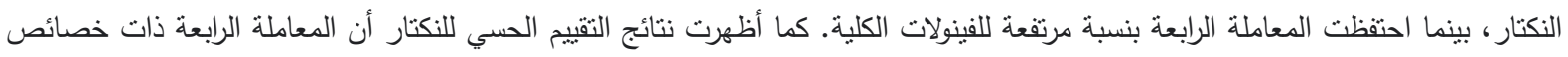

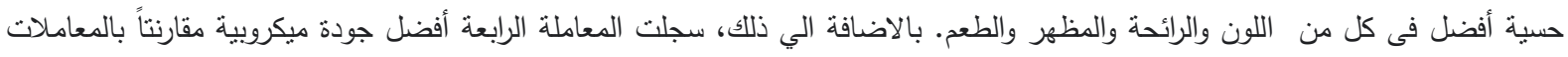

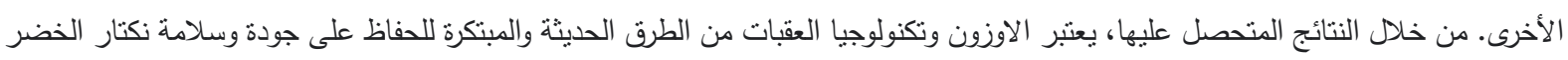

